\title{
Rancang Bangun Sistem Pilkades Menggunakan Teknologi Smart Card Sebagai Kartu Pemilih
}

\author{
I Putu I Permana ${ }^{\mathrm{a} 1}$, I Ketut G Darma Putra ${ }^{\mathrm{a} 2}$, I Gusti M A Sasmita ${ }^{\mathrm{a} 3}$ \\ aJurusan Teknologi Informasi, Fakultas Teknik, Universitas Udayana \\ Jalan Kampus Bukit Universitas Udayana, Bali, Indonesia \\ 1indrappermana@gmail.com \\ 2darma.putra@ee.unud.ac.id \\ 3aryasasmita83@gmail.com
}

\begin{abstract}
Abstrak
Pemilihan Kepala Desa (Pilkades) merupakan proses yang tidak terpisahkan dari Negara Indonesia sebagai negara demokrasi. Pilkades saat ini masih menggunakan sistem pemungutan suara (voting) secara konvensional, menggunakan media kertas untuk melakukan proses pemilihan. Pelaksanaan sistem voting konvensional tersebut mempunyai banyak kelemahan seperti menghitung hasil voting relatif lebih lama dan menggunakan perhitungan manual. Perkembangan dan kemajuan teknologi informasi saat ini dapat dimanfaatkan untuk mendukung pelaksanaan voting Pilkades secara lebih baik yang menjadi solusi cerdas akan kemajuan teknologi yang dapat menggantikan sistem voting konvensional, yaitu dengan media sistem elektronik voting (e-voting) menggunakan teknologi smart card sebagai kartu pemilih. Sistem dikemas dalam bentuk aplikasi yang dipasang/di-install pada komputer dan reader/writer tools sebagai media untuk membaca/menulis pada smart card. Sistem e-voting Pilkades dengan teknologi smart card telah berhasil dijalankan dan menghasilkan dashboard hasil voting Pilkades dengan menunjukkan jumlah voting dalam bentuk angka, persentase (\%), grafik dan diagram.
\end{abstract}

Kata kunci: Pemilihan Kepada Desa (Pilkades), E-Voting, Smart Card, Reader/Writer Tool, Teknologi Informasi.

\begin{abstract}
Village Head Election (Pilkades) is an inseparable process in the State of Indonesia as a democracy country. Pilkades today still uses a voting system conventionally, using media in form of paper to conduct the electoral process. Implementation of the conventional voting system has many weaknesses, such as the time to count the voting results are relatively longer and it still uses manual calculation. The advance development in recent information technology can be used to support the better implementation of the Pilkades voting which expected to be a smart solution that in the future may replace the conventional voting system, for example by electronic voting system (e-voting) which is using smart card technology as a voter card. The system is packaged in the form of apps installed on the computer and a reader/writer tool as a media to $\mathrm{read} / \mathrm{write}$ on the smart e-voting card. Pilkades system with smart card technology has been successfully executed and in the dashboard apps is shown the number of voting in Pilkades voting results in the form of numbers, percentages (\%), graphs and charts.
\end{abstract}

Keywords: Village Head Election (Pilkades), E-Voting, Smart Card, Reader/Writer Tool, Information Technology.

\section{Pendahuluan}

Indonesia merupakan negara yang menganut sistem politik berbasis demokrasi yang artinya memberikan hak pilih atau voting kepada setiap warga negara yang telah memenuhi persyaratan untuk pengambilan keputusan dalam menentukan para wakil rakyat atau kepala daerah. Sistem electronic voting ( $E$-Voting) adalah evolusi dari sistem voting bersifat konvensional yaitu dengan menggunakan kertas sebagai media untuk melakukan pemilihan menjadi sistem pemilihan 
berbasis aplikasi yang diterapkan pada komputer serta pengolahan data hasil voting langsung oleh sistem dan mendapatkan hasil cepat dari voting yang telah dilaksanakan. Salah satu contoh wilayah yang sudah menerapkan sistem e-voting adalah Kabupaten Jembrana, Bali. Kabupaten Jembrana sudah menerapkan sistem e-voting untuk melakukan pemilihan kepala daerah (Pilkada), menggunakan kartu KTP elektronik (E-KTP) sebagai alat untuk melakukan voting Pilkada. Wilayah Bali sendiri memiliki Kabupaten yang tentunya terdapat Desa. Desa dipimpin oleh Kepala Desa (Kades). Proses pemilihan Kepala Desa (Pilkades) setiap desa masih menggunakan sistem voting konvensional, yang mempunyai kelemahan seperti menghitung hasil voting relatif lebih lama serta menggunakan perhitungan secara manual yang juga memiliki resiko pada akurasi hasil voting, sehingga diperlukan sistem e-voting Pilkades di desa dengan pemanfaataan smart card sebagai kartu pemilih [1]. Penerapan Sistem e-voting Pilkades dapat memberikan solusi cerdas terkait dengan akurasi hasil dan kecepatan perhitungan suara. Teknologi yang digunakan pada sistem e-voting Pilkades dengan smart card dan reader/writer tool sebagai pembaca data yang dimiliki warga sesuai persyaratan voting Pilkades. Aplikasi sistem e-voting Pilkades diharapkan dapat bermanfaat untuk desa dan memudahkan warga melakukan pemilihan di tempat pemungutan suara.

\section{Metodologi Penelitian}

Metode e-voting berdasarkan data smart card yang berupa data warga. Prinsip kerja dari sistem e-voting pilkades adalah sistem e-voting mendeteksi smart card yang di-scan melalui reader/writer tool oleh pemilih, apabila data cocok dan terdaftar pada sistem, maka sistem akan melanjutkan langkah menampilkan foto dari calon kepala desa yang akan dipilih oleh pemilih. Pemilih akan melakukan pemilihan dengan meng-klik dari foto calon kepala desa dan sistem akan menyimpan hasil voting dari pemilih yang telah melaksanakan kewajibannya dengan baik. Hasil voting ditampilkan melalui halaman administrator sistem berupa dashboard hasil voting.

\subsection{Flowchart Penggunaan Aplikasi}

Diagram alir (flowchart) penggunaan aplikasi merupakan suatu alur secara keseluruhan dari penggunaan aplikasi e-voting pilkades ini. Alur dimulai dari melakukan scan terhadap smart card pemilih, kemudian aplikasi membaca data smart card pemilih lalu menampilkan foto calon kepala desa yang ada pada sistem. Berikut diagram alir (flowchart) untuk penggunaan aplikasi ini dapat dilihat pada Gambar 1. Secara umum proses dari aplikasi ini adalah user menggunakan smart card sebagai identitas digital yang akan di-scan melalui reader/writer tool yang sudah terintegerasi pada aplikasi lalu aplikasi e-voting akan mencocokan data dalam database. Data sesuai dan terverifikasi maka tahap selanjutnya menampilkan halaman voting yaitu foto calon Kepala Desa, lalu meng-klik foto calon Kepala Desa, kemudian muncul halaman terima kasih yang berisi kata-kata terimakasih telah menggunakan kewajiban dengan baik. Jika pemilih melakukan kecurangan dengan sengaja meng-scan kembali smart card, maka muncul validasi bahwa data pemilih pada smart card sebelumnya telah melakukan voting.

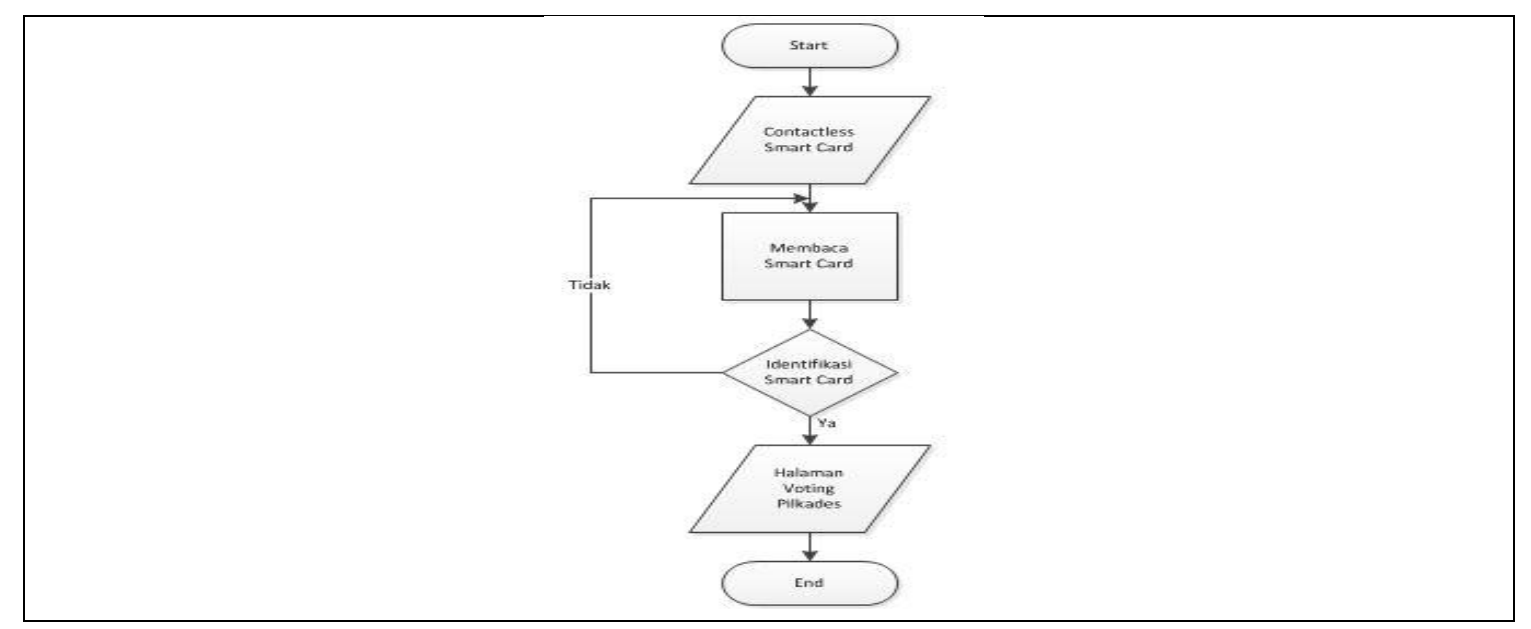

Gambar 1. Flowchart penggunaan Aplikasi 


\subsection{Gambaran Umum Sistem}

Aplikasi Sistem E-Voting Pilkades ini diakses oleh satu pemilih. Pemilih adalah warga yang sudah terverifikasi dalam sistem untuk melakukan voting. Pemilih menggunakan aplikasi ini dengan media komputer, sebagai media voting Pilkades yang diselenggarakan oleh panitia setempat.

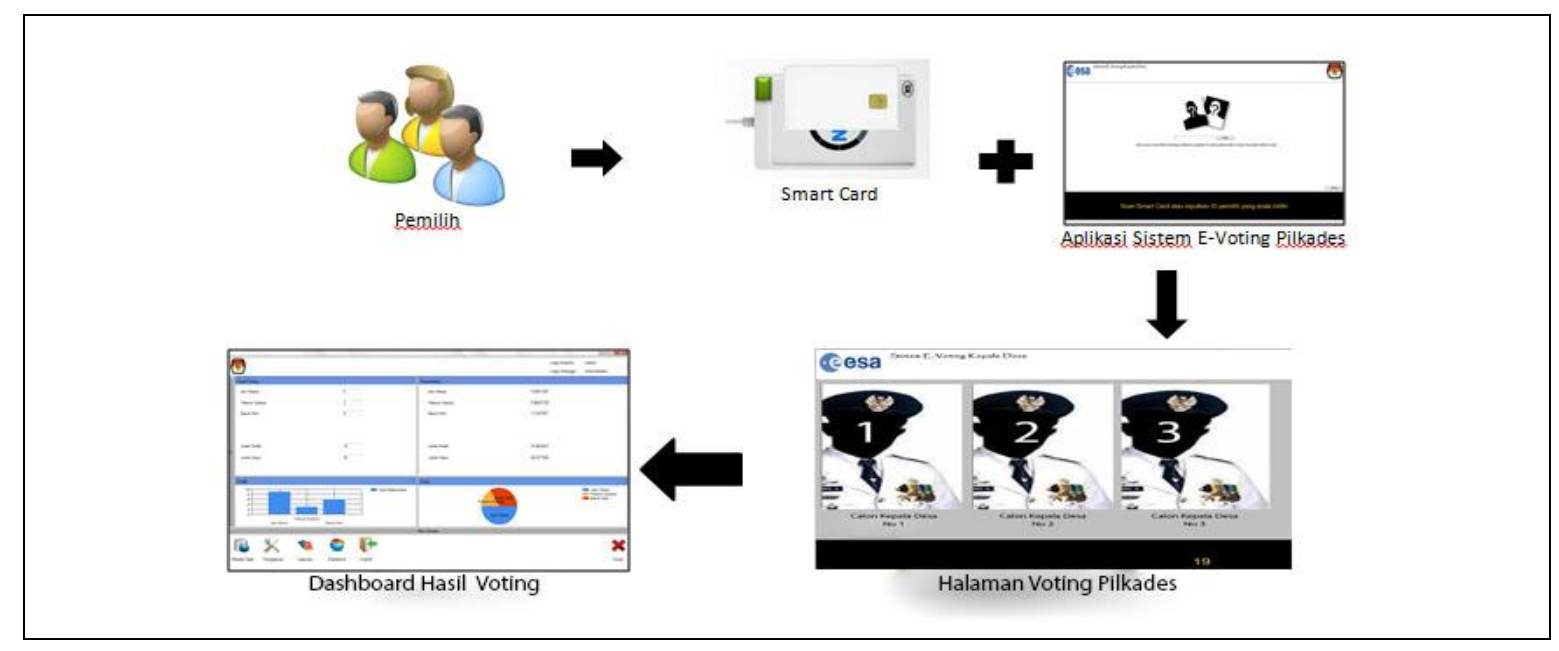

Gambar 2. Gambaran Umum Sistem

Gambaran umum aplikasi pada Gambar 2 memperlihatkan interaksi yang terjadi antara pemilih dengan aplikasi e-voting Pilkades, dimana pengguna berinteraksi dengan smart card serta reader/writer tool yang terintegerasi pada sistem e-voting Pilkades. Pemilih melakukan voting calon Kepala Desa, dan menghasilkan dashboard hasil voting Pilkades.

\subsection{Data Flow Diagram (DFD)}

Design Data Flow Diagram (DFD) pada aplikasi sistem e-voting memiliki fungsi untuk menggambarkan proses aliran data yang terjadi pada sistem dari tingkat tertinggi sampai terendah dari sistem. Sistem e-voting Pilkades memiliki Context Diagram (DFD Level0) dan DFD Diagram Level 1 yang menunjukkan alur data sistem adalah sebagai berikut.

\subsubsection{Context Diagram (DFD Level 0)}

Context diagram merupakan diagram pertama dalam rangkaian suatu DFD yang menggambarkan suatu entity saling berhubungan dengan sistem dan aliran data secara umum. Proses yang lebih detail terdapat dalam sistem masih belum dapat diketahui [6]. Desain context diagram sistem e-voting Pilkades ditunjukkan pada Gambar 3 yang memiliki dua external entity, yaitu pemilih dan admin.

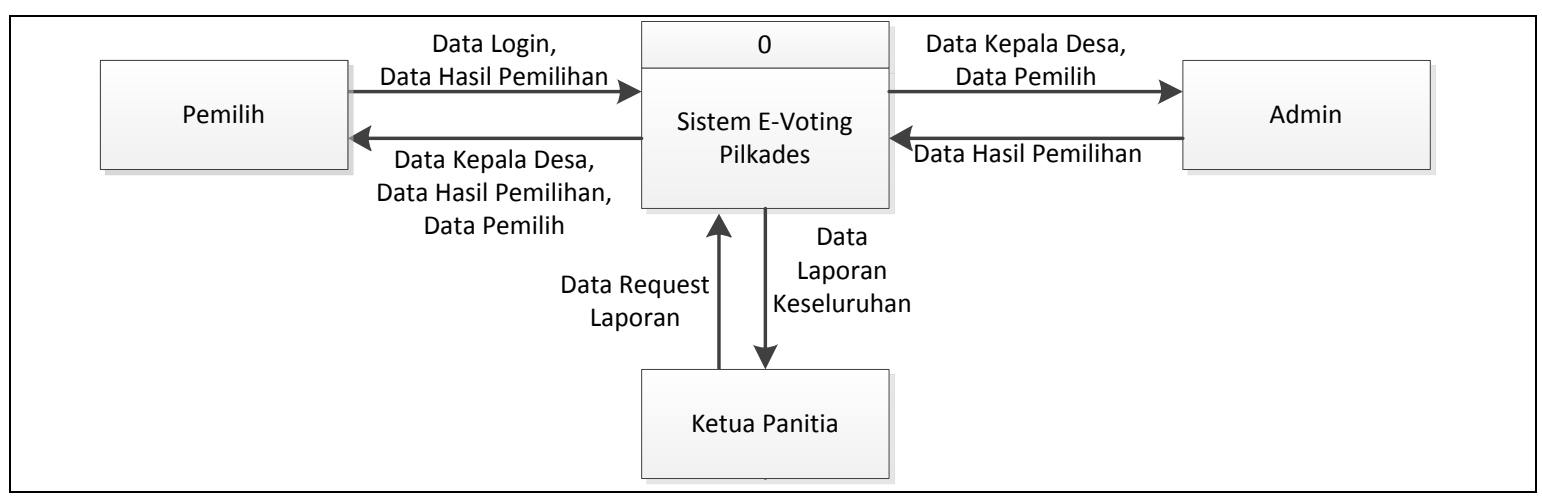

Gambar 3. Context Diagram Sistem E-Voting Pilkades 


\subsubsection{DFD Diagram Level 1}

Context diagram pada sistem e-voting Pilkades dikembangkan lagi sehingga menjadi diagram aliran data tingkat satu, yang memuat rincian dari diagram konteks sebelumnya. DFD Level 1 dilihat dari pengolahan sistem e-voting Pilkades, yang memiliki 5 proses utama adalah sebagai berikut.

a. Manajemen Pemilih

b. Manajemen Calon Kepala Desa

c. Manajemen Autentifkasi

d. Manajemen Voting

e. Manajemen Hasil Voting

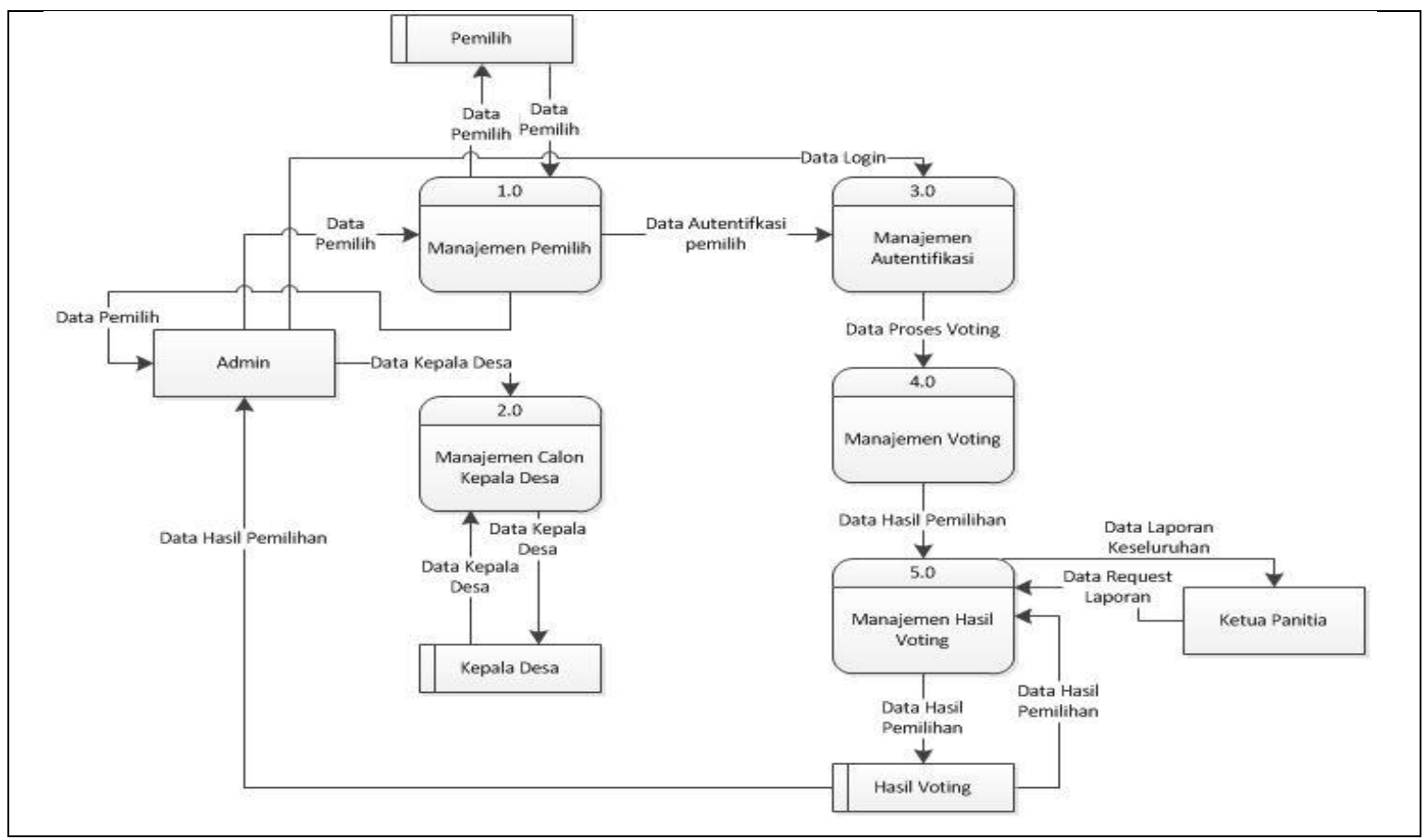

Gambar 4. DFD Level 1

\subsection{Entity Relationship Diagram (ERD)}

Sistem e-voting Pilkades ini memiliki 4 buah entitas yaitu Administrator, Calon Kepala Desa, Pemilih dan Hasil Voting. Administrator menginputkan data warga dan data calon Kepala Desa ke sistem. Warga telah resmi menjadi pemilih tetap, mendapatkan smard card sebagai kartu pemilih. Pemilih mengakses sistem e-voting Pilkades dengan melakukan login dengan mengscan smart card, lalu masuk pada halaman voting Pilkades. Halaman voting pilkades, akan muncul kandidat calon Kepala Desa dan dipilih langsung oleh warga. Sistem menyimpan data pilihan dari pemilih ke dalam database dan mengolahnya dengan menghitung jumlah suara masing-masing calon Kepala Desa, jumlah pemilih atau penduduk yang memilih dan jumlah penduduk yang tidak memilih kemudian menampilkan hasil pemungutan suara. Gambar 5 menampilkan ERD dari sistem e-voting Pilkades. 


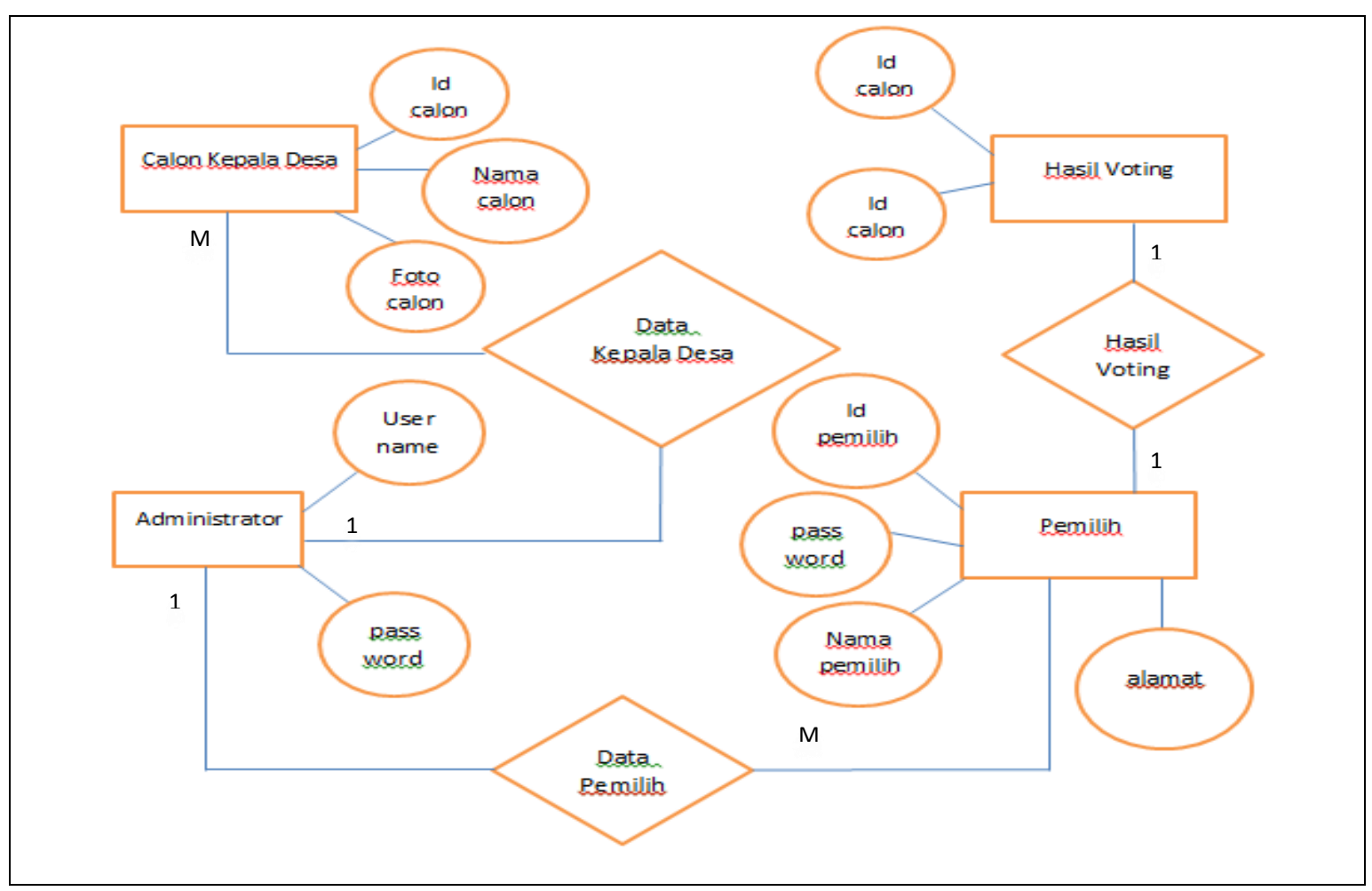

Gambar 5. ERD Sistem e-voting Pilkades

\section{Kajian Pustaka}

Kajian Pustaka memuat semua pustaka yang dijadikan acuan pada penelitian Aplikasi Sistem EVoting Pilkades. Pustaka didapat dari berbagai referensi baik jurnal ilmiah, maupun buku-buku.

\subsection{Skema E-Voting}

Skema e-voting adalah satu set protokol yang menjaga keamanan atau kerahasiaan oleh pemilih dalam melakukan pemilihan serta interaksi dengan panitia pemilihan dan perhitungan suara. $E$ Voting pada umumnya dibedakan menjadi dua tipe, yaitu E-Voting Online (sistem via internet) dan E-Voting Offline (dengan menggunakan mesin penghitung suara atau kertas suara) [2].

Tujuan dari keamanan sistem e-voting adalah menjamin kerahasiaan pemilih dan keakuratan pilihan. Keamanan sistem e-voting memiliki beberapa kriteria adalah sebagai berikut.

a. Eligibility and Authentication adalah hanya pemilih terdaftar yang dapat memberikan suara.

b. Uniqueness adalah pemilih hanya dapat memilih sekali.

c. Accuracy adalah sistem harus dapat menyimpan pilihan dengan benar.

d. Integrity adalah sistem harus menjamin pilihan tidak dapat diubah, dipalsu dan dihapus tanpa deteksi.

e. Verifiability and Auditability adalah sistem memungkinkan pengecekan pilihan untuk memeriksa bahwa semua pilihan telah dihitung dengan benar dan harus ada rekaman pilihan yang asli dan terpercaya.

f. Reliability adalah sistem harus dapat bekerja dengan benar tanpa kehilangan satupun pilihan meskipun bila terjadi permasalahan berat pada mesin atau jaringan komunikasi.

g. Secrecy and Non-Coercibility adalah sistem harus menjamin kerahasiaan setiap pemilih untuk mencegah terjadinya penjualan atau pemaksaan suara [3].

Pelaksanaan e-voting di Indonesia, pertama kali diselenggarakan pada pemilihan Kepala Daerah di Kabupaten Jembrana, Bali. Berikut ini adalah Gambar 6 yang menunjukkan alur Sistem EVoting Kabupaten Jembrana. 


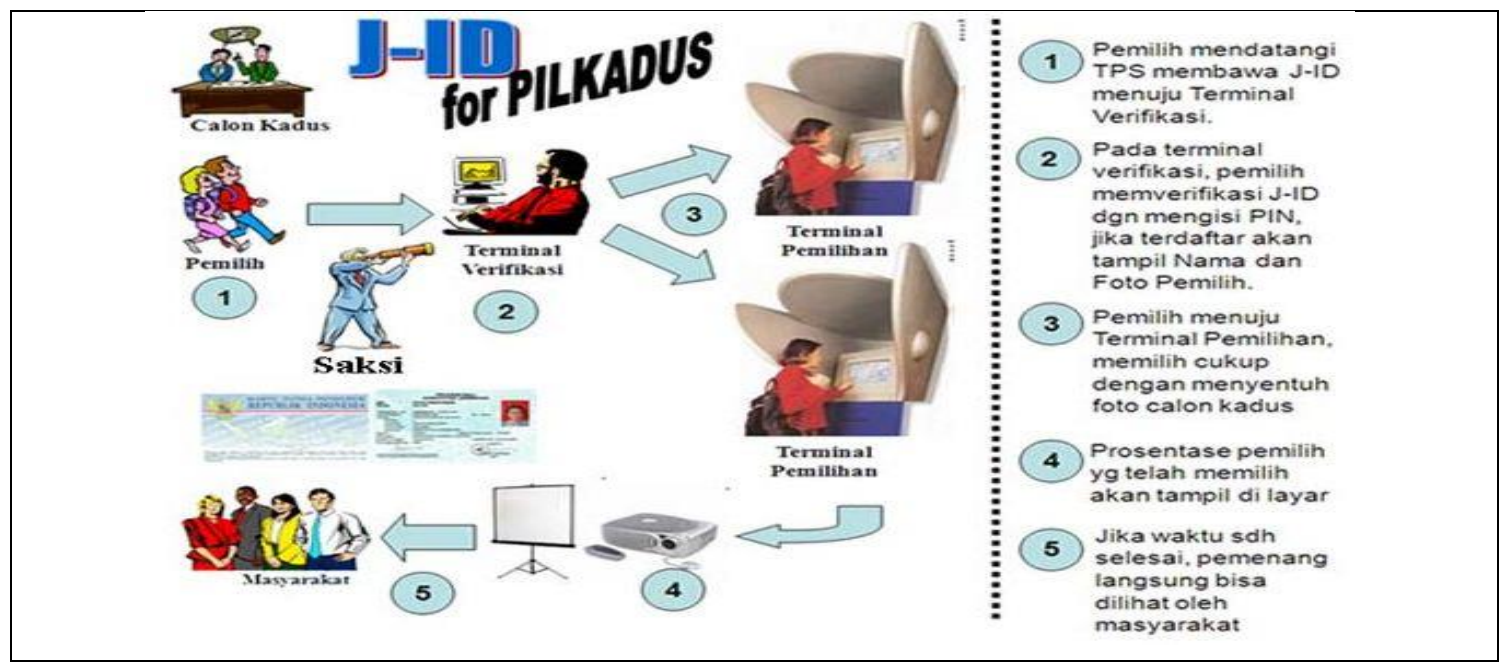

Gambar 6. Gambar alur Sistem E-Voting Kabupaten Jembrana [4]

\subsection{Contactless Smart Card}

Kartu pintar atau smart card adalah Chip Card atau Intergrated Circuit Card (ICC) merupakan kartu plastik yang berukuran sama dengan kartu kredit, yang didalamnya terdapat chip silicon disebut microcontroller. Chip terdiri dari rangakaian terintegerasi (Integerated Circuit), yaitu prosesor dan memory. Chip pada smart card berfungsi untuk melaksanakan perintah dan menyediakan power ke smart card [5]. Gambar 7 menunjukkan kartu pintar atau smart card.

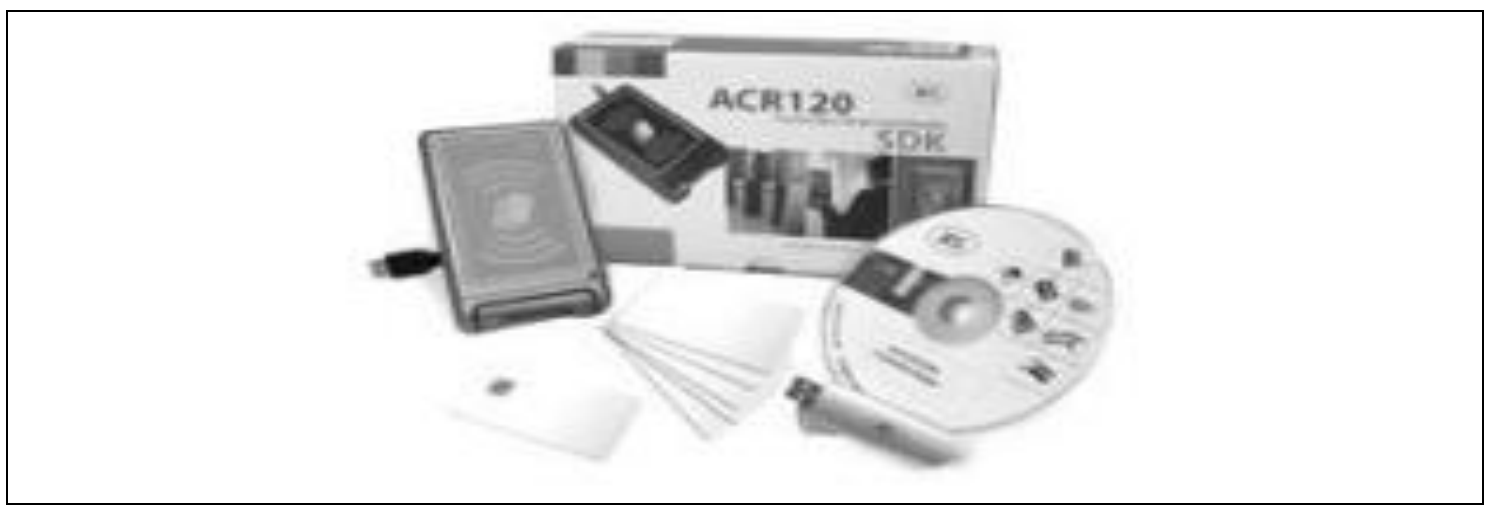

Gambar 7. Contactless Smart Card

Salah satu komponen yang penting dalam penggunaan teknologi ini adalah aspek keamanan. Data yang tersimpan biasanya berupa data bersifat rahasia, hanya boleh diakses oleh pihak yang memiliki wewenang. Mekanisme pengamanan yang spesifik untuk melindungi informasi yang disimpan dalam smart card. Mifare contactless smart card memiliki mekanisme pengamanan yang baik, tetapi bentuknya standart, sehingga setiap pihak yang mengetahui strukturnya akan dapat menembus keamanan dari smart card [6].

\section{Hasil dan Pembahasan}

Tujuan dari pembuatan aplikasi ini adalah untuk mengembangkan sistem e-voting Pilkades, menerapkan teknologi smart card dan menghasilkan informasi dan laporan untuk manajemen pengelola e-voting Pilkades. 


\subsection{Halaman Pendaftaran Pemilih}

Sistem pendaftaran pemilih adalah proses saat pemilih mengisi form pendaftaran dengan benar, kemudian sistem akan memasukkan data pendaftaran ke dalam database dusun sesuai dengan dusun yang dimasukkan oleh pemilih. Gambar 8 adalah tampilan untuk pendaftaran pemilih.

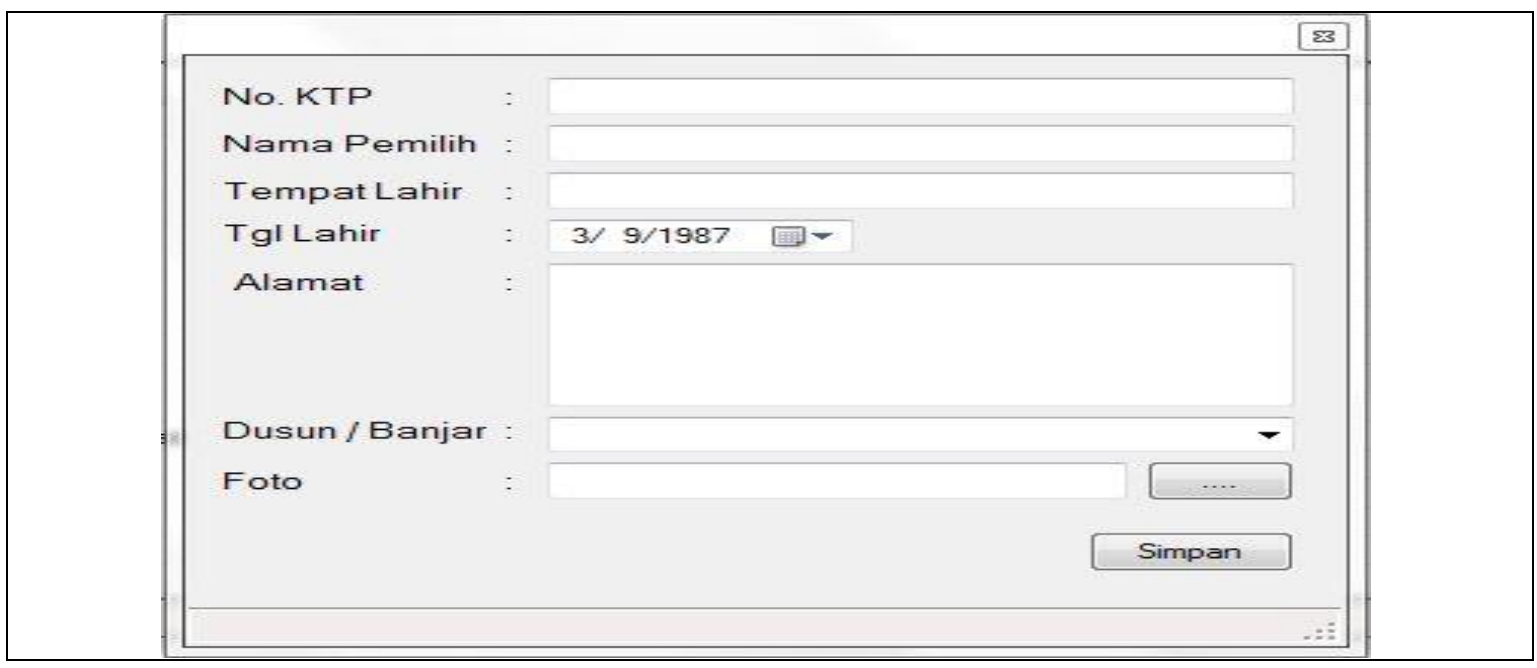

Gambar 8. Halaman Pendaftaran Pemilih

\subsection{Verifkasi Data Pemilih}

Proses verifikasi pemilih merupakan tahapan verifikasi pemilih menjadi daftar pemilih tetap (DPT) untuk dapat melakukan e-voting Pilkades menggunakan smart card. Verifikasi pemilih menjadi DPT telah dilakukan, selanjutnya pemilih mendapatkan smart card yang nantinya sebagai kartu pemilih untuk melakukan e-voting Pilkades. Gambar 9 merupakan tampilan verifikasi data pemilih menjadi DPT dengan meng-klik Button Verifikasi Pemilih Tetap.

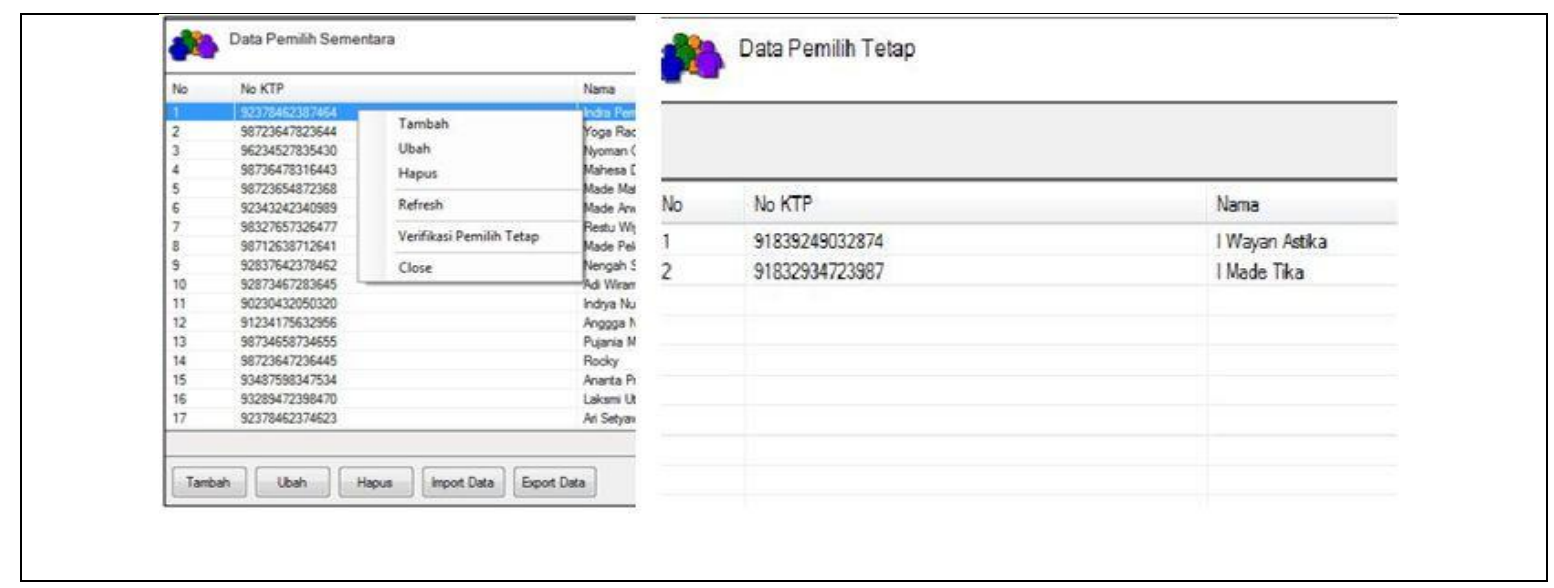

Gambar 9. Verifikasi Data Pemilih Menjadi Data Pemilih Tetap (DPT)

\subsection{Verifikasi Data Pemilih Tetap (DPT) pada Smart Card}

Proses verifikasi data pemilih tetap (DPT) pada smart card merupakan tahap menulis/writing data pemilih pada smart card dengan reader/writer tools. Data pemilih tersimpan dalam memory smart card, kemudian digunakan untuk e-voting Pilkades. Gambar 9 menjelaskan, data pemilih pada halaman DPT tersebut di-klik kanan dan pilih button tulis ke smart card, lalu data pemilih disimpan dalam memory smart card. 


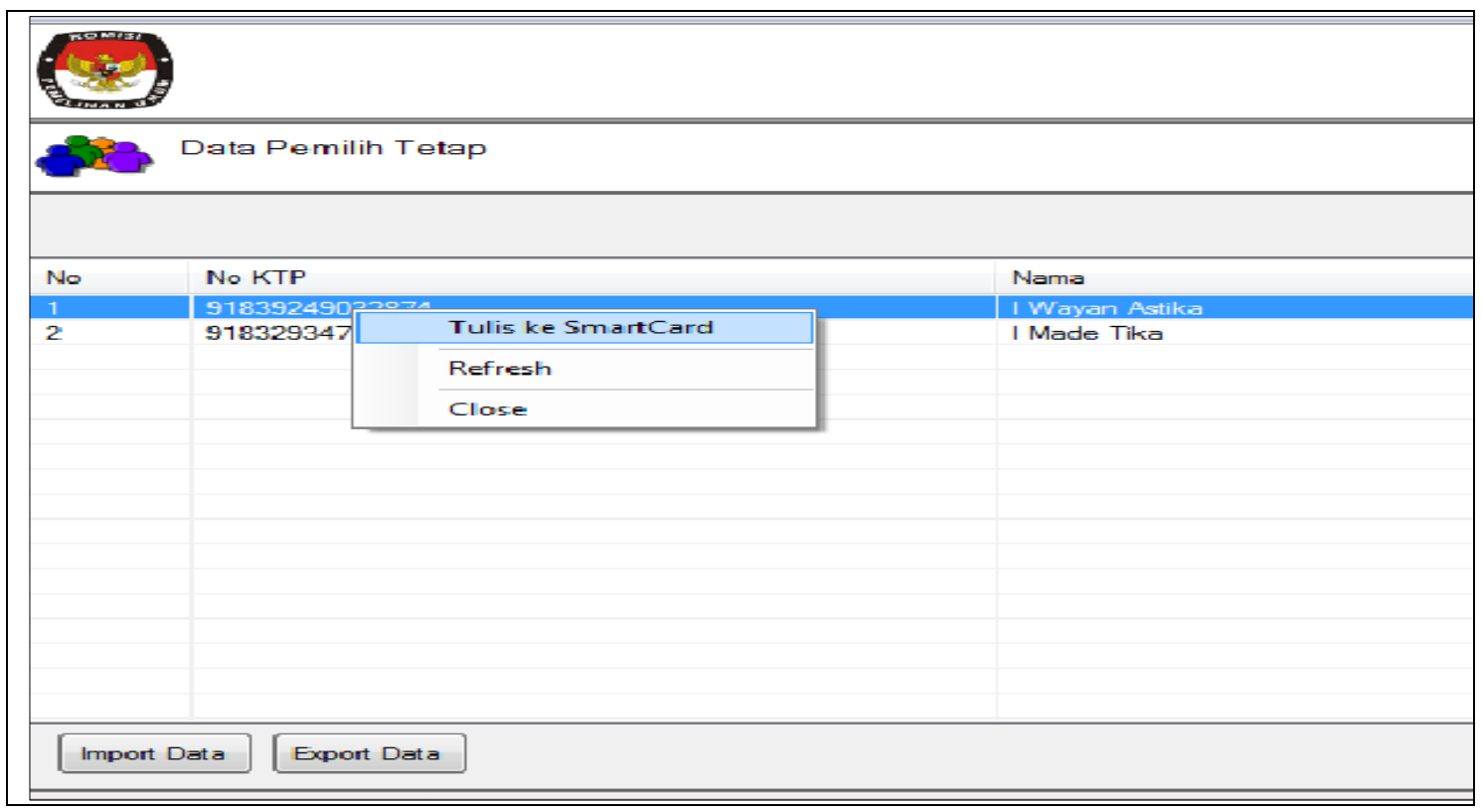

Gambar 10. Verifikasi Data Pemilih Tetap (DPT) pada Smart Card

\subsection{Proses Absensi Data Pemilih}

Absensi data pemilih berfungsi untuk mendata kembali warga sebagai pemilih dengan mengabsensi sebagai tanda hadir serta menunjukkan bahwa benar data pada smart card sesuai dengan pemilih. Absensi dalam proses wajib dilakukan agar dapat melakukan e-voting Pilkades, jika ada pemilih tidak melakukan proses absensi, maka pemilih tidak bisa melakukan proses $e-$ voting Pilkades.. Gambar 11 menunjukkan halaman hasil absensi data pemilih.

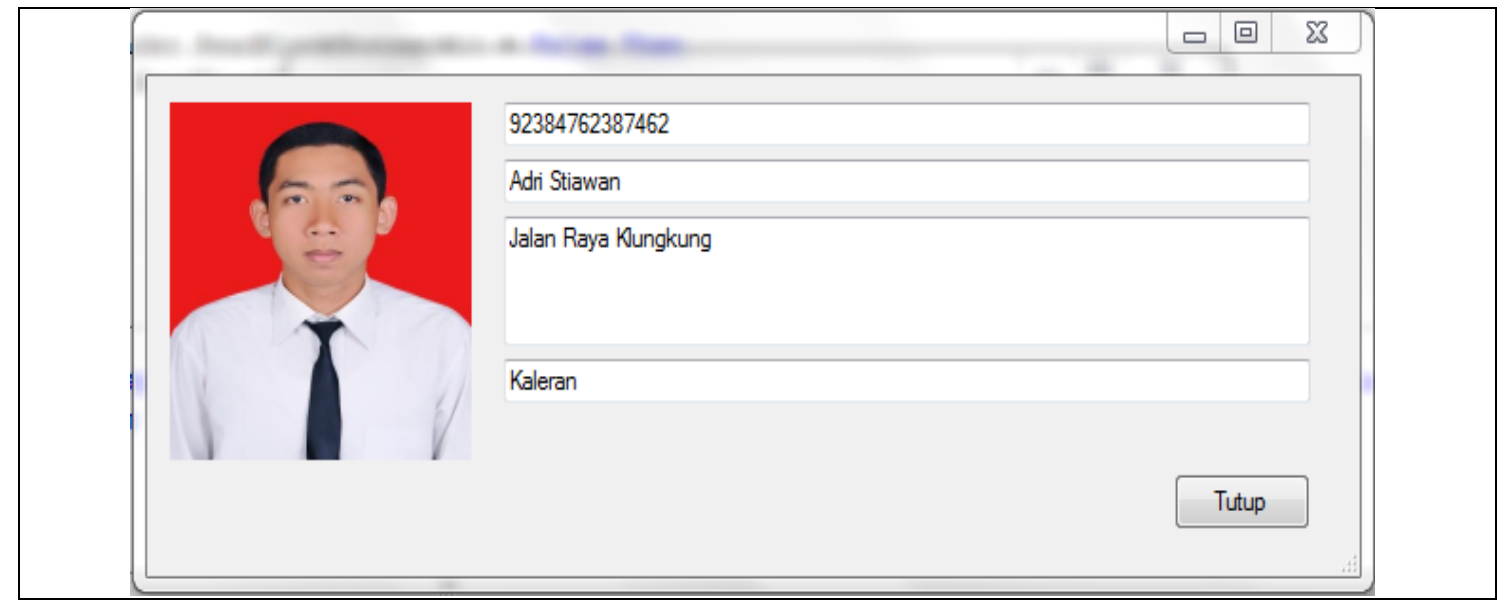

Gambar 11. Halaman hasil absensi data pemilih

\subsection{Proses E-Voting Pilkades}

Data pemilih yang sudah tersimpan dalam smart card kemudian dipergunakan dalam proses evoting Pilkades. Gambar 12 menunjukkan halaman voting dengan proses pemilih melakukan scan smart card, masuk ke sistem voting dan melakukan voting calon kepala desa. 


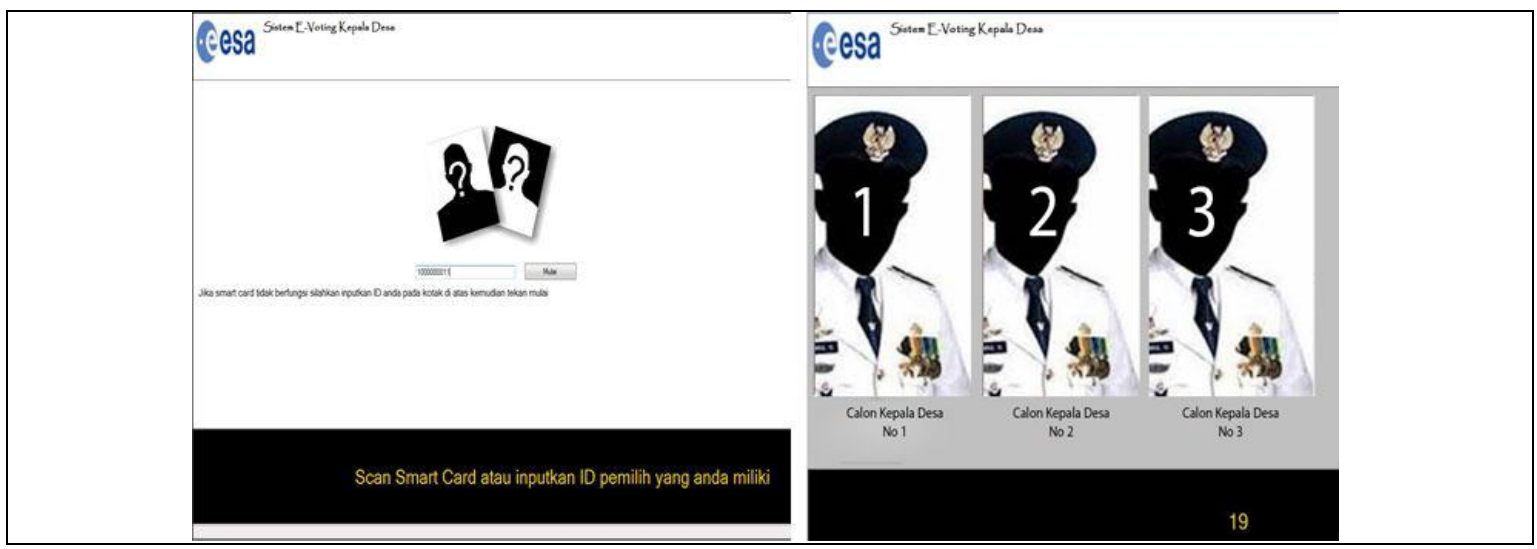

Gambar 12. Proses E-Voting Pilkades

\subsection{Dashboard Hasil E-Voting Pilkades}

Dashboard hasil e-voting Pilkades menunjukkan hasil setelah pemilih melakukan e-voting Pilkades. Gambar 13 menunjukkan dashboard hasil voting Pilkades dengan menampilkan jumlah voting dalam bentuk angka, persen (\%), grafik dan diagram.

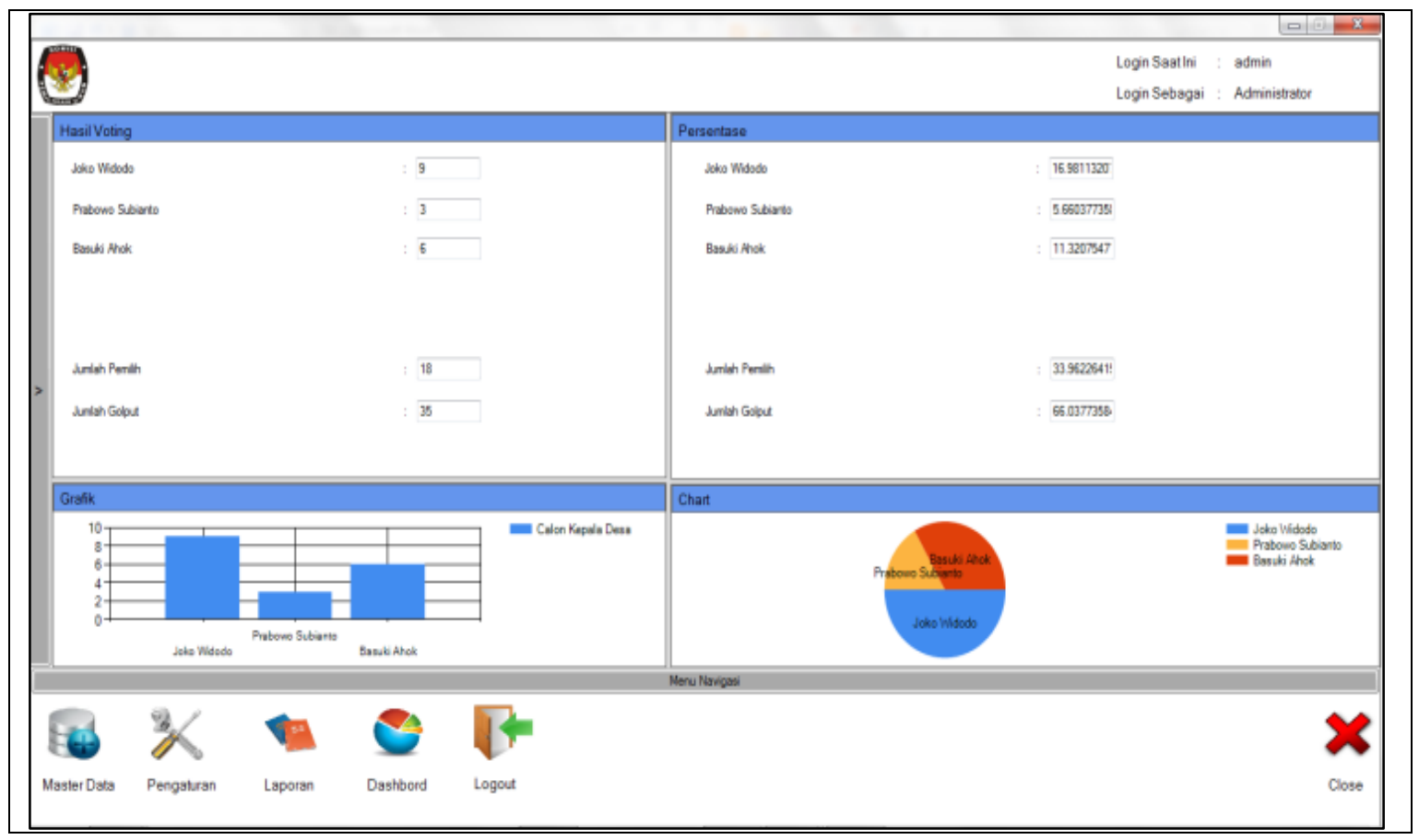

Gambar 13. Dashboard Hasil E-Voting Pilkades

\section{Kesimpulan}

Pemilihan secara electronic (e-voting) memiliki banyak keunggulan, yaitu dapat menghemat waktu dan tenaga sumber daya terutama dalam proses perhitungan suara. Waktu pemilih melakukan voting Pilkades lebih cepat dan hemat tenaga sumber daya karena aplikasi sistem sudah dirancang untuk mendapatkan langsung hasil voting yang lebih cepat dan akurat. Penelitian ini berhasil menerapkan sistem e-voting Pilkades yang terdiri dari sistem pendaftaran pemilih, verifikasi data pemilih, verifikasi data pemilih dengan smart card, absensi data pemilih, proses e-voting Pilkades dan dashboard hasil voting dengan menampilkan jumlah voting dalam bentuk angka, persen (\%), grafik dan diagram. 


\section{Daftar Pustaka}

[1] A. Rokhman, "Prospek dan tantangan penerapan e-voting di indonesia," in Seminar Nasional Peran Negara dan Masyarakat dalam Pembangunan dan Masyrakat Madani di Indonesia, 2011, pp. 1-11.

[2] S. Canard and H. Sibert, "How To Fit Cryptographic E-Voting Into Smart Cards," in IOS Press, 2011.

[3] "Jembrana Voting" [Online]. Available: http://www.jembranakab.go.id/index.php?module=evoting [diakses tanggal 1 Februari 2016].

[4] Advance Card System, ACR120S Contactless Reader/Writer Communication Protocol. 2006.

[5] C. I. Kurnia, H. Tanuwijaya, and T. Sagirani, "Rancang Bangun Sistem Informasi Food Crount pada Pusat Pembelanjaan Smart Surabaya," Jurnal Sistem Informasi, vol. 2, no. 2, 2013. 